\title{
The Impacts of the Turkish Government's Conspiratorial Framing of the Gezi Park Protests
}

\section{Abstract}

What happens when a prime minister frames a momentous protest as a foreign conspiracy? The Turkish government's reaction to the Gezi Park protests, a reaction centred on a conspiracy theory about an 'interest rate lobby,' provides a unique case to explore the impacts of conspiracy theories about big-scale protests. Relying on quantitative and qualitative content analysis of online users' responses to the government's conspiracy theories, I discuss the socio-political significance of this conspiratorial rhetoric. The findings demonstrate that (1) the previous political views of online users predict their responses to conspiracy theories, and (2) the users' comments were centred on their perceptions of the government. These show that people tend to interpret the conspiracy theories in line with their political values and interests, and, accordingly, that the government's conspiratorial frames concerning the protests seem to have contributed to the political fragmentation by enhancing the division between the Justice and Progress Party (AKP) supporters and opponents.

\section{Keywords}

Conspiracy theories, frames, Gezi Park protests, political communication, Turkey

At times, conspiratorial accounts as such can become widespread government explanations and influence the destinies of nations: Nazi Germany legitimized its horrendous policies via anti-Semitic conspiracy theories (Bronner, 2003). Despite their apparent and at times escalating socio-political significance, current academic literature does not adequately 
analyze how conspiracy theories are interpreted by people. For example, the scholarship lacks empirical analyses on the impacts of conspiracy theories about social movements.

What scholarship there is, devoid of a sufficient amount of empirical research, has two tendencies: (1) tarnishing the reputation of conspiracy theories by presenting them as paranoid and extremist views, (2) describing them as people’s rational/instrumental attempts to understand social reality. I will call the former attitude classical approach and the latter cultural perspective. As expressed by Hofstadter's (1965) 'paranoid style' description, the former understands conspiracy theories as biased, value-laden accounts that fail to explain the real nature of events and as products of political extremism (Aaronovitch, 2009; Byford, 2011; Pipes, 1997; Robins \& Post, 1997). Scholars have stated that conspiracy theories promote monological belief systems, which incline their readers to believe in the rest of the conspiracy literature (Goertzel, 1994). Bale (2007) adds that conspiracy theorists fail to explain the real conspiracies that are taking place, because their monolithic accounts overlook the complex and pluralistic nature of conspiracy making. The cultural perspective disagrees with the pathologization of conspiracy theories and views them as people's attempts to understand social reality (Birchall, 2006; Bratich, 2008; Gray, 2010; Knight, 2000; Locke, 2009; Melley, 2000; Olmsted, 2009). Gosa (2011) claims that the conspiratorial accounts of hip-hop culture document and challenge racial inequality in the United States. Fenster (1999) underlines a need to transcend this division between the classical and cultural perspectives because, while the cultural perspective is unable to explain the value-laden nature aspects of a conspiracy theory, the classical approach cannot conceptualize its socio-political rationale.

The social movements literature on the use of cultural frames (e.g. Benford \& Snow, 2000; Halfmann \& Young, 2010; Snow, Tan, \& Owens, 2013) has not explored the significance of conspiratorial accounts. Nevertheless, some studies highlight the relevance of conspiracy theories: Hart (2008) suggests that the conspiratorial framework of the John Birch Society 
was not the most influential factor leading people to join the movement; Leenders (2012) claims that the President Bashar al-Assad's attempt to discredit the protests in Dar'a backfired, as crowds gathered again to protest his conspiracy frame; Chakravarty and Chaudhuri (2012) argue that anti-witch-hunt movements in India used conspiratorial frames about the exploitation of the tribal population, which helped them to forge a common identity.

This contribution enriches the scholarship on social movements and conspiracy theories by focusing on the Turkish government's conspiratorial accounts about the Gezi Park protests. High-level government officials, including the Prime Minister of the period, Recep Tayyip Erdoğan, used accusations of conspiracy when explaining the reasons behind the protests in 2013. I explore the socio-political significance of these conspiracy theories via a content analysis of online users' responses to the conspiracy theories on the most popular Turkish forum website, Ekşi Sözlük. In line with Boudon's (2014) rational choice perspective, I scrutinize the instrumental/rational and value-laden reasons that lead people to accept or reject conspiracy theories and show that there is a relationship between online users' political orientations and their perceptions of the Turkish government's conspiracy theory concerning the Gezi Park protests. Accordingly, I suggest that political values and interests are the best estimates of people's opinions about conspiracy theories. That is to say, people who believe in conspiracy theories are not solely rationally or irrationally attempting to grasp reality; they also defend their interests and values. In the case of the conspiracy rhetoric on the Gezi Park protests, the online users might support the conspiratorial idea because they are AKP supporters, even though they might not believe that it is true. This argument helps to transcend the division between the classical and cultural perspectives and instead affords a sociological approach.

First, the article contextualizes the government's rhetoric on the Gezi Park protests by providing a historical overview of the popular conspiratorial frames in Turkish politics. 
Second, it outlines its theoretical perspective on the perception of conspiracy theories. Third, the paper describes the context of the research by recounting the Gezi Park protests and introducing the Ekşi Sözlük website. Subsequently, it presents the findings and concludes with a discussion of their implications.

\section{A Historical Overview of the Conspiratorial Framing in Turkish Politics}

In his seminal work, Goffman (1975, p. 21) claims that people use frames to 'locate, perceive, identify and label' everyday events and make sense of the world through the basic frameworks. Benford and Snow (2000) see frames as 'conceptual scaffolding' by which social movements construct and modify political messages. They claim that social movements articulate diagnostic, prognostic and motivational frames to mobilize support (Snow \& Benford, 1988). Diagnostic frames define social problems; Prognostic frames propose a course of action to stop these problems, and motivational frames provide reasons to lead people to collective action. From this perspective, conspiracy theories can be viewed as a specific type of diagnostic frame that attempts to explain what is 'really' going on as a consequence of secret plots of powerful groups and individuals. Indeed, according to Uscinski and Parent (2014, p. 32), conspiracy theories cite 'as a main causal factor a small group of powerful persons, the conspirators, acting in secret for their own benefit against the common good.' Hart (2008) describes the anti-communist conspiratorial rhetoric of the John Birch society as diagnostic frames.

This could help to explore why some conspiratorial theories are historically persistent frames in certain contexts. For example, Turkish politics is replete with conspiratorial frames on various topics (Bora, 1996) ranging from minorities (Baer, 2013) to the plots of secret state institutions, the so-called deep state (Kavakçı, 2009). According to the Turkish Prime Minister at the time of the Gezi protests, Recep Tayyip Erdoğan, an interest rate lobby 
conspired against the Turkish government in the Gezi Park protests. Although Erdoğan has not exactly pointed at who constitutes this clique, he broadly refers to a secret international group profiting from high interest rates in Turkey. It is difficult to trace the exact genealogy of the conspiratorial style in Turkish politics. Nevertheless, the content of the 'interest rate lobby' argument is a popular conspiratorial frame that could be traced back to the establishment of the Turkish Republic in the early $20^{\text {th }}$ century.

The Ottoman Empire, the predecessor of the Turkish Republic, collapsed due to ethnic minority independence movements in the $19^{\text {th }}$ and early $20^{\text {th }}$ centuries. In that period, nearly all political and intellectual movements in the empire attempted to find a solution to avoid the complete dismemberment of the Ottoman land. Most of these efforts saw modernization of the country as a solution. For example, the introduction of sociology to the Turkish context by the Committee of Union and Progress (CUP), one of the most important players of the Ottoman modernization, was polity-oriented to save the country. These efforts rendered fruitless at the end of the First World War in 1920, and the Sèvres Treaty between the Ottoman Empire and the allied countries allocated large portions of the Ottoman territory to the allied powers as well as Kurds and Armenians. Consequently, Turkish forces, led by the founding father of the Turkish Republic, Mustafa Kemal Atatürk, waged the Independence War (1919-1923) against the occupying countries and secured the contemporary borders of Turkey in the subsequent Lausanne Treaty in 1923.

The complete breakup of the Ottoman Empire at the end of the First World War led to widespread conspiratorial views about plotting foreign agents and the internal groups they use as pawns. Recent scholarship has labelled this conspiratorial approach as Sèvres syndrome, which refers to an anxiety about the alleged threat of conspiring foreign powers and their internal collaborators to the Turkish Republic (Aras, 2009). The impacts of this conspiracy frame have been observed in the school curriculum (Webb, 2011), the perception 
of the European Union (EU), isolationist state policies (Y1lmaz, 2011), foreign policy (Aras, 2009) and the Kurdish insurrection (Aydınl1, 2002; Robins, 2003). Guida (2008) remarks that the syndrome has shaped Turkish intellectuals’ perception of society and politics. Göçek outlines three stages of the Sèvres syndrome: (1) the Republican elite began to perceive the Sèvres Treaty as a proof of threats in the early 20th century; (2) prominent political actors helped the reproduction of the syndrome; and (3) the power of the syndrome weakened at the end of the Cold War (Göçek, 2011). Y1lmaz (2011) states that Turkish right-wing parties propagate the syndrome to voice their scepticism of Turkey's EU candidature: the MHP saw the EU requirements as a manifestation of the Western agenda of dividing Turkey by creating 'artificial minorities' in the country. Further, since the beginning of the Turkish Republic, the state ideology has continuously attempted to avoid and eliminate any potential causes for social antagonisms, e.g. class differences (Mello, 2007) and ethnic differences (Üngör, 2011), which could be seen as a product of its anxiety about the potential exploitation of internal conflicts by foreign powers.

The AKP's proposition of the interest rate lobby conspiracy theory is another version of the conspiratorial frame of the Sèvres syndrome, as it warns about alleged plots of global powers and their local collaborators. In other words, the government's frame could be seen as a cultural fabrication (Snow et al., 2013) that is produced by calling forth and building on the conspiratorial style of the Sèvres syndrome. In so doing, the government attempts to delegitimize the protests by presenting them as a product of foreign enemies. Like social movements' uses of grotesque images (Halfmann \& Young, 2010), this could be productive by creating strong negative emotions among the public and leading them to associate the protests with wrongdoing, or it could backfire if people find the government's conspiratorial frame incredible. 


\section{Interpreting Conspiracy Theories: Political Orientation as an Indicator}

Rational choice theory, which takes the purposive actions of individuals as the starting point for understanding social systems (Coleman, 1990), can enable us to understand the rationale of people in interpreting the government's conspiratorial frames about the Gezi Park protests. The perspective's emphasis on delineating individuals' reasons for action can unveil the reasons for accepting or rejecting the conspiracy theory. We can develop an understanding of people's responses to the conspiratorial rhetoric in the following way: (1) on a macro-level, the Turkish government proposes the conspiracy theory concerning the Gezi Park protests; (2) on a micro-level, an individual interprets the conspiracy theory according to his/her interests and values; (3) he/she comments on the conspiracy theory on Ekşi Sözlük and responds to the macro-politics. In this way, rational choice perspective could help to explain the dissemination and impacts of the conspiracy theory on both the micro- and macro-levels.

In this study, I build on Boudon's (1996, 2001, 2003, 2008, 2014) version of rational choice theory, which focuses on instrumental and value-laden rationale as determinants of individual behavior. First, I examine the conspiracy theory as a product of instrumental rationale, as people might use conspiratorial accounts pragmatically for their political benefit, for example to accuse their opponents without even necessarily being sure about the veracity of the accusations. Second, in line with Boudon's (2003) cognitivist theory of action, which highlights a view of conspiracy theories as value-laden narratives, I pay heed to the values people refer to in their comments regarding the conspiracy theory, such as believing that, by their very nature, certain evil groups always conspire to gain power. Indeed, the model has already been affording a theoretical tool to explore the rationale of non-conventional beliefs. Rydgren (2004), using Boudon's perspective, posits that xenophobic views may be subjectively rational and attempts to illustrate people’s logic to hold such beliefs by referring to erroneous inferences they make. 
I use Boudon's model by focusing on the political orientations of the online users as an explanatory variable, because they reflect the political values and interests of the online users. I scrutinize the relationship between their previous political posts and their responses to the government's conspiratorial rhetoric. This strategy does not mean that people's values and interests are all tied to their political views. It is solely a pragmatic tool to explore the impacts of the government's rhetoric. Indeed, conspiracy theories are political narratives that describe power relations as being dominated by secret actors, and the content of the online conversation about the Turkish government's conspiracy theory was politically oriented. I claim that the online users consider the conspiracy theory in line with their political values and interests. Previous studies already underline the importance of people's political orientations in interpreting and proposing conspiracy theories (see Fathi, 2014; Nefes, 2012, 2013, 2014, 2015a, 2015b). In their comparison between Republicans and Democrats in the United States, Uscinski and Parent (2014) find that people accept and reject conspiracy theories in line with their political orientations. Gray (2014, p. 288) suggests that the political elite use conspiracy theories pragmatically in the Middle East.

This perspective could help to provide a bridge between frame theory and rational choice perspective in the study of social movements. Indeed, Goffman (1959, p. 162) underlines the important balance between instrumental rationality and value rationality: 'Our activity, then, is largely concerned with moral matters, but as performers we do not have a moral concern in these moral matters. As performers we are merchants of morality.' He suggests that people follow moral rules and regulations not passively but actively in line with their interests. Moreover, Hart (2008), in his analysis of the John Birch Society's conspiratorial rhetoric, concludes that people join this movement organization not because they agree with its conspiratorial rhetoric, but because it gives them an opportunity to publicly perform their conservative identity. This shows that value-rationality and instrumental rationality can both 
influence people’s decisions to join a group disseminating conspiratorial ideas. Following the values they respect, they take part in the group, but using their rationality, they do not believe in the conspiratorial framework the Birch Society advocates. This model could be relevant in our discussion on the reception of the interest rate conspiracy theory.

\section{Contexts}

\section{The Gezi Park protests}

The Gezi Park protests were a wave of demonstrations and sit-ins in Turkey and beyond, which took place in May and June 2013. They began as an issue-based small 'occupy style' resistance to the Turkish government's attempt to demolish the Gezi Park in Taksim, one of the few green areas in central Istanbul, in order to build a shopping mall, despite not having any legal permission to uproot the trees (Diken, 2014; Kuymulu 2013). On 28 May 2013, around 50 protesters camped in Gezi Park to prevent the demolition, and they were supported by politicians such as Sırrı Süreyya Önder, a Member of Parliament (MP), and Kemal Kıliçdaroğlu, another MP and the leader of the Republican People's Party (CHP). Turkish police raided the protesters' camp twice in the dawns of 30 and 31 May, fired tear gas and burnt the protestors' tents in order to make them give way to the demolition vehicles.

Police aggression did not prevent the rapid growth and spread of the protests to other cities, such as Ankara and Izmir. The event turned into a historically significant demonstration in Turkey, which brought together a wide range of political groups, unions and civil societies, such as environmentalists, 'anti-capitalist Muslims,' gay and lesbian groups, football supporter clubs, and members of various political parties (Balli, 2013). The police force withdrew from Gezi Park and Taksim Square on 1 June until 11 June (Amnesty International, 2013). The area stayed under the control of the protesters, who organized various activities ranging from concerts to yoga classes (Gambetti, 2014). On June 15, police forcefully moved 
in and cleared the encampment in the park. On 23 June, the Minister of Interior of the period, Muammer Güler, stated that approximately 2.5 million people participated in the protests in 79 out of 81 cities in Turkey and that around 4,900 people were detained (Amnesty International, 2013).

Many high-level government officials, especially Prime Minister Erdoğan, constantly sought to discredit the protestors. On June 1, Erdoğan stated that he could gather many more people than the protesters (Haaretz, 2013). On June 2, he called the protesters marauders (çapulcu) and declared that the protests would not stop the demolition plans (Arsu, 2013). Many protesters reacted ironically by labelling themselves as çapulcu. Although other officials did not contradict Erdoğan's views, at times they took softer stances: Deputy Prime Minister Bülent Arınç apologized for 'excessive violence' against protesters; President Abdullah Gül praised the peaceful protesters; and Ali Babacan, another Deputy Prime Minister, declared that the government respected the non-violent protests and free speech (Aljazeera, 2013). Nevertheless, the government's rhetoric was full of conspiratorial frames concerning the events (Keyder, 2013). Erdoğan described the protests as a conspiracy against Turkey by internal traitors and their foreign collaborators including social media, companies and the interest rate lobby: 'social media was prepared for this, made equipped. The strongest advertising companies of our country, certain capital groups, the interest rate lobby, organizations on the inside and outside, hubs, they were ready, equipped for this' (Hürriyet Daily News, 2013a). According to this view, reminiscent of the anti-Semitic conspiracy theory about Jewish bankers' secret control over the world economy, the interest rate lobby attempted to hinder Turkish economic progress by triggering these events. On 1 July, the Deputy Prime Minister, Beşir Atalay, argued that the Jewish Diaspora was behind the events (Reuters, 2013). An AKP lawmaker of the period, Burhan Kuzu, declared that Germany was one of the foreign conspirators among others, because the Turkish government was building a 
new airport which would diminish the importance of Frankfurt International Airport (Hürriyet Daily News, 2013b).

The protests were the most significant demonstrations in Turkey in recent decades. Some of the immediate consequences of the events were visible in economics and the Turkey-EU relationship. In June 2013, the Turkish stock exchange fell 10.5\% in one day after investors acknowledged their concerns about the demonstrations (BBC, 2013). The German government suggested delaying a new round of the EU membership talks with Turkey for four months to convey the EU's disapproval of the Turkish government's handling of the events (Croft \& Pawlak, 2013). Amnesty International (2013) condemned the Turkish government's response to the protests and the ensuing police violence, which they saw as a blatant disregard of the right to peaceful assembly.

In contrast to the government's response, many scholars address the reasons for the mobilisation of the protesters and frame the events as a spontaneous democratic uprising of people against the authoritarian tendencies of the Turkish government (Bakıner, 2014; Eken, 2014; Farro \& Demirhisar, 2014; Göle, 2013; Gürcan \& Peker, 2014; Iğsı, 2014; Moudouros, 2014; Örs, 2014). Diken (2014, p. 322) underlines that the protesters have found the courage to disobey the state authority, and by facilitating this, the demonstrations had a significant impact on Turkish politics. Keyder (2013) notes that the main actor of the protest was the well-educated and globally connected 'new middle class.' The only systematic survey about the protests, conducted on-site with 4,411 protesters by a well-known research company in Turkey, supports this claim by showing that, proportionally, the protesters had higher levels of education than the Istanbul average and the proportion of the protesters with white-collar jobs was higher than the proportion of white-collar workers living in Istanbul (KONDA, 2014). Moreover, the same research company conducted a nationwide survey with 2,629 respondents and found that the likelihood of supporting the protests was positively 
correlated with income levels and living in big cities (KONDA, 2014). With regards to the conspiracy frame, Özbudun (2014) claims that the AKP attempted to mobilize and consolidate its own supporter base.

\section{Ekşi Sözlük}

Founded in 1999, Ekşi Sözlük is a collaborative hypertext dictionary based on the concept of websites built upon user contributions. In September 2014, Ekşi Sözlük was the $27^{\text {th }}$ most popular website in Turkey, and the most popular site acting mainly as a forum in Turkish. Akça (2010) underlines that Ekşi Sözlük fosters democratic rational-critical discourse by enabling its users to engage in all kinds of political debates without censorship. Ekşi Sözlük created an online community of people from a broad range of classes, ideologies and groups, who talk about things that cannot be discussed elsewhere. It should be added that, through an ethnographic observation of the online usernames, which implied a good command of English on the part of the online users, and the user comments about the conspiracy theory, I would speculate that the demographic profile of the users matched the protester profile in Keyder’s (2013) argument (i.e. a 'new middle class').

The website provides an ideal medium in which to explore the political communication of the conspiracy theory because of (1) its registration system, which ensures that each user is identified with a unique username and prevents the same people from putting entries under different usernames, (2) being the most popular internet medium for political discussions in Turkey, (3) enabling its users to trace individual users' previous comments, and (4) constituting an online public forum, where ideas are freely discussed. 


\section{Method}

The analysis relies on quantitative and qualitative content analyses of online discussions about the interest rate lobby conspiracy theory on Ekşi Sözlük. While the quantitative analysis enables us to see whether there is a statistically significant relationship between political orientations of the users and their perceptions of the conspiracy theories, the qualitative analysis provides an in-depth view of how the online users reject or accept these accounts. I examine entries about users' views on the conspiracy theory from the day Erdoğan proposed it, 7 June 2013, until 1 July 2014, as well as the online users' political orientations acknowledged before 7 June 2013, to explore the relationship between their political views and their proclivity to accept/reject the conspiratorial rhetoric. In total, there were 643 entries from 461 online users on the interest rate lobby topic. I eliminated irrelevant and unclear entries with regards to the users' political views and perspectives on the conspiracy theory, and the study ultimately explored 437 entries from 372 online users. The unit of analysis for the study is individual user. When there was more than one entry from an individual user with regards to the conspiratorial rhetoric, I coded them together under one category from their overall meaning. This strategy enables a focus on individuals' perceptions and their uses of the conspiratorial rhetoric. Besides, individual users' comments on the Gezi Park protests and their previous political entries did not vary much from each other, and only 26 users had more than one entry with regards to the government's conspiracy rhetoric.

\section{Coding Categories}

As Table 1 below illustrates, I categorized the online entries about the interest rate lobby into two. First, there were people who agreed with the conspiracy theory. They supported the argument and/or quoted people who claimed that the interest rate lobby existed. Second, the 
remaining users proposed that the interest rate lobby argument was wrong and/or quoted people who rejected the government's account.

\section{[TABLE 1 ABOUT HERE]}

Moreover, I focused on the other political entries of the online users before the Gezi Park protests to discern their political stance concerning the AKP. These were most often comments on the AKP rule and Recep Tayyip Erdoğan and clearly showed the political orientation of the online users. Hence, as explained below, there was full agreement between four coders with regards to the political orientations. Pro-AKP users made comments such as: 'By selling the roads and bridges the government did another great job... people who criticize the government for this have no idea about the new global political-economy;' 'You cannot discriminate against AKP supporters. I am one of them too.' They also showed a strong support and admiration to the leader of the AKP: 'Erdoğan is a great leader, who cannot be taken down;' 'He is the most successful leader of Turkey ever;' 'He took all the risks to solve the most important problem of Turkey [the Kurdish conflict]. If Allah wills it, he shall be victorious again.' The online users with anti-AKP orientation also expressed their views lucidly: 'People, who insist on voting for AKP, are masochists;' 'During the AKP governance, there has been a lot of international money laundering in Turkey, which they present as an economic growth;' 'It is crystal clear that Turkey has reached the last stop before fascism during the AKP rule.' Furthermore, some of the ways they showed dislike of Erdoğan are as follows: 'I would be very happy when he dies;' 'Erdoğan does not care about the founding principles of the Constitution of Turkey. He slanders the founding fathers of this country;' 'Erdoğan lies about the economy.' 


\section{Inter-coder Reliability}

First, I read the entries and constructed the coding categories. Then, I coded the material twice on separate occasions a month apart and underlined 23 non-matching cases. In order to establish the reliability of the content analysis (Hayes \& Krippendorff, 2007; Lombard, Snyder-Duch, \& Bracken, 2002), I invited three colleagues to separately code randomly chosen parts of the material. As I did not have funding for the coders, this was done on a voluntary basis. I sent around 90 entries concerning the interest rate lobby argument and additional entries about the political views of 10 users to each coder and compared their coding with mine. To measure the level of reliability, the study calculated both percentages of agreements of the coders as well as Krippendorf's alpha $(\alpha)$, which accounts for the probability of agreeing by chance (Potter and Levine-Donnerstein, 1999).

The results showed that, with regards to the political orientations of the online users, there was $100 \%$ agreement (Krippendorf's alpha=1.0) between the other coders and myself. About the comments on the interest rate lobby, with the first coder there was $98 \%$ agreement in coding (Krippendorf's alpha=0.79). With the second coder, there was 94\% agreement (Krippendorf's alpha $=0.52$ ), while with the third coder, there was $100 \%$ agreement (Krippendorf's alpha=1.0). The reason for the high rates of agreement between coders might be due to the dual categories of opposite stances, which simplified the coding process. In the few cases of disagreement, I contacted the coders, and we came to a common decision. The limitation is that around $70 \%$ of the comments were double-coded, and the rest were coded only by me. Nevertheless, the simplicity of the coding process and the high levels of reliability are strong indicators for the validity of the analysis. 


\section{Does political orientation predict the perception of the conspiratorial frame?}

Table 2 below illustrates that, while 337 users rejected the conspiratorial rhetoric, 35 users were convinced by the interest lobby argument. Among the people who rejected the conspiratorial frame, only one online user's political orientation was pro-AKP, while the remaining 336 users had anti-AKP leanings. The balance with regards to political orientation is in the opposite direction among the online users who accepted the government's rhetoric: 12 of them were anti-AKP, while the remaining majority of 23 users were sympathetic towards the AKP government.

\section{[TABLE 2 ABOUT HERE]}

A logistic regression analysis was conducted to predict people's beliefs in the conspiratorial rhetoric using their previous political perspective as predictor. A test of the full model against a constant only model was statistically significant, indicating that the predictor as a set reliably distinguished between acceptors and decliners of the conspiracy theory (chi square=119.336, $\mathrm{p}<.000$ with $\mathrm{df}=1$ ). Moreover, Nagelkerke’s $\mathrm{R}$ Square is 0.591 , indicating a relationship between prediction and grouping. As can be seen in Table 3 below, the overall prediction success was $96.5 \%$ (99.7\% for declining and $65.7 \%$ for accepting the conspiracy theory). In addition, the Wald criterion demonstrated that previous political views made a significant contribution to prediction $(p=.000)$. The $\operatorname{EXP}(B)$ value indicates that, when a user's previous political view changes from anti-AKP to pro-AKP, the odds ratio is 644 times as large and, therefore, the online user is 644 more times likely to believe the conspiracy theory. In short, the statistical analysis very clearly shows a significant relationship between the previous political views of the online users and their interpretations of the government's conspiratorial rhetoric.

[TABLE 3 ABOUT HERE] 


\section{Rationale for rejecting and accepting the conspiratorial frame}

The entries that agreed with the conspiracy theory as propagated by Erdoğan were categorized as Erdoğan right. As shown in Table 4 below, some online users agreed with the conspiratorial rhetoric as well as quoting people who supported their stance. Second, the entries denoted the conspiracy exists in a different form proposed that, although there was an interest rate lobby, it was not as Erdoğan claimed. They argued that the lobby acted in line with the AKP government throughout their rule as an ally. The third type of entries, Erdoğan wrong, suggested that the interest rate lobby argument was factually wrong. Many of these responses mocked the government's rhetoric by claiming that it was a translation error, as faiz means both interest and interest rate in English, and they claimed that Erdoğan's advisors probably translated the word interest lobby from a report as faiz lobisi (i.e. interest rate lobby) (Aş1k, 2013). They also made sarcastic comments like pretending to be employed by the lobby. Other entries, called AKP propaganda, rejected the government's account. They stated that, although the AKP government knew that the interest rate lobby did not exist, they put forward this false claim to delegitimize the protests.

\section{[TABLE 4 ABOUT HERE]}

The ways in which people responded to the conspiracy frame are in line with the results of the quantitative analysis, which shows a relationship between political orientation and the perception of the conspiracy theory. The users' responses were shaped by their political views. First, most of the comments focused on the source of the conspiracy theory, the AKP government, rather than the dubious existence of the conspiratorial argument. The online users often supported their views about the conspiracy theory with their perception of the AKP. Second, even when people believed in the existence of the interest rate lobby, as shown in the conspiracy exists in a different form argument, they still rejected the government's 
rhetoric by arguing that the lobby was a political ally of the government. These online users all had anti-AKP leanings. Hence, it could be inferred that, while they believed in the existence of the lobby, their anti-AKP leanings prevented them from agreeing with the government's account. Third, the AKP supporters who joined the debate were tolerant enough to take part in a discussion with an anti-AKP tone. Despite their liberal attitude, with only one exception, they all agreed with the government's conspiracy theory. It could be argued that more conservative AKP supporters would be much less likely to reject the government's conspiratorial account, which supports the premise that there is a relationship between conspiratorial views and political orientation. Last, the rejection types are not exogenous for presenting the users' perceptions, because an online user could agree with all rejections despite mentioning only one. However, they are still significant in terms of portraying how people reasoned in the online forum concerning the conspiracy frame.

It should not go without exploring the main contrasting cases to the argument. 12 users with anti-AKP tendencies accepted the government's conspiracy rhetoric. As the quantitative analysis shows, this group comprises a small minority that does not change the statistically significant relationship between previous political views and interpretation of the conspiratorial rhetoric. Regardless, a deeper qualitative look into these users' entries enables us to see in which cases previous political views do not influence people's interpretations of conspiracy theories. In all 12 entries, the online users express a strong previous belief in the existence of the interest rate lobby. For example, a user commented that 'in the current times of global capitalism, almost everyone is under the influence of the power of the interest rate lobby;' another online user stated that 'in the United States, the accomplices of the interest rate lobby caused a big fall of the stock market in one day.' One user noted that s/he was told by a trusted friend about the existence of this conspiratorial clique and concluded that: ‘...this is a historically very significant group. We should not continue mocking the government for 
its argument on the interest rate lobby.' In addition to these, five other users still disagreed with the government's account by arguing that they did not describe the interest lobby accurately. All in all, these cases show that previous beliefs in conspiratorial rhetoric could influence people’s interpretations of conspiracy theories at times.

\section{Conclusion}

The findings support the premise that there is a relationship between online users' political orientations and their perceptions of the Turkish government's conspiracy theory about the Gezi Park protests. The quantitative analysis illustrates that their political orientations predict the online users' approach to the conspiratorial rhetoric. While the AKP sympathizers tended to believe in the government's conspiratorial rhetoric, almost all AKP opponents in the sample questioned the veracity of the conspiracy theory. In parallel, the qualitative analysis indicates that the online users' comments about the government's account were replete with their political views about the AKP. Most of the comments reflected the political orientations of the online users, whose rationales for rejection or acceptance often relied on their perception of the AKP. Overall, the article highlights the significance of political interests and values in understanding the socio-political impacts of conspiracy theories.

This contribution provides important insights into the literature on social movements and politics in Turkey and beyond. To start with, people in the sample interpreted conspiracy theories in line with their political orientations. This could imply that the government's conspiracy frame functioned to consolidate the AKP's supporter base against the protests, to alienate the people sympathizing with the protests and, consequently, to increase the political fragmentation between the protesters and the AKP supporters. That is to say, the conspiratorial style in Turkish politics could be seen as a powerful frame to discredit social movements by solidifying political fragmentation between government supporters and 
protesters. One major limitation of this argument is that it does not rely on a nationally representative data and therefore might not be attributable to the entire population. Nevertheless, the data provides strong evidence for the main premise of this paper. Second, the study notes the prominence of the conspiratorial political style in Turkey. The government's use of conspiracy frames is emblematic of how this style could easily prevail in mainstream Turkish politics. Moreover, the AKP's vision of plotting powerful foreign actors and pawn-like insiders, the Sèvres syndrome, points at the historical continuity of the conspiratorial style in Turkish politics since the early 20th century. Furthermore, the AKP government, a popular target of conspiratorial rhetoric for a decade, did not refrain from proposing conspiracy theories against its opponents. This not only echoes the premise that political actors use conspiracy theories in line with their interests and values, but also shows that conspiracy theories could be disseminated by any political actor in Turkish politics, no matter their ideological orientations.

The classical and cultural perspectives, which view conspiratorial thinking either as political pathology or alternative ways of thought, are informed by the finding that political actors actively reject, accept and manipulate conspiracy theories in line with their values and interests. In other words, this study reaches beyond the division between the classical and cultural perspectives and moves the discussion forward by showing that conspiratorial thinking cannot be solely categorized as marginal ideas or alternative thinking in the face of rapid changes in society. It introduces Boudon's (2001) rational choice perspective as an alternative theoretical standpoint that enables an understanding of conspiracy theorising as a consequence not only of cost-benefit analysis but also of normative value considerations.

Future studies could build on these conclusions by looking into nationwide representative survey data on the impacts of conspiracy theories. Moreover, they could conceptualize conspiracy theories as a type of propaganda and consider their impacts by taking people's 
political orientations into account. Explanations of these ostensibly irrational phenomena would afford important insights into socio-political conflicts and ethno-religious hostilities and hatred, which are often ignited, legitimized and perpetuated by conspiratorial rhetoric.

Note

1. The article greatly benefited from the insightful comments of Michael Biggs, the anonymous reviewers and the editor.

\section{References}

Aaronovitch, D. (2009). Voodoo histories: The role of the conspiracy theory in shaping modern history. London: Jonathan Cape.

Akça, H. (2010). The Internet as a participatory medium: An analysis of the eksisozluk website as a public sphere. University of South Carolina, ProQuest, UMI Dissertations Publishing. Retrieved from http://search.proquest.com/docview/746773010

Aljazeera. (June 6, 2013). Turkey protests continue despite apology. Retrieved from http://www.aljazeera.com/news/europe/2013/06/20136551212442132.html

Amnesty International. (2013). Gezi Park protests: Brutal denial of the right to peaceful assembly in Turkey. London: Amnesty International Ltd.

Aras, B. (2009). Turkey's rise in the greater Middle East: Peace-building in the periphery. Journal of Balkan and Near Eastern Studies, 11, 29-41.

Arsu, S. (2 June, 2013). Turkish leader says protests will not stop plans for park. Retrieved from http://www.nytimes.com/2013/06/03/world/europe/turkey-premier-says-protests-will$\underline{\text { not-stop-plans-to-demolish-park.html? } \mathrm{r}=0}$ 
Aşık, M. (June 19, 2013). Interest lobby... Milliyet. Retrieved from http://www.milliyet.com.tr/interest-lobby-/gundem/ydetay/1724810/default.htm

Aydınlı, E. (2002). Between security and liberalization: Decoding Turkey's struggle with the PKK. Security Dialogue, 33, 209-225.

Baer, M. (2013). An enemy old and new: The Dönme, anti-Semitism, and conspiracy theories in the Ottoman Empire and Turkish Republic. Jewish Quarterly Review, 103, 523-555.

Bale, J. (2007). Political paranoia v. political realism: On distinguishing between bogus conspiracy theories and genuine conspiratorial politics. Patterns of Prejudice, 41, 45-60.

Balli, A. (June 1, 2013). Turkey: Police clash with Istanbul Gezi Park protesters. BBC. Retrieved from http://www.bbc.co.uk/news/world-europe-22732139

BBC. (3 June, 2013). Turkish stock market falls 10.5\% as demonstrations escalate. Retrieved from http://www.bbc.co.uk/news/business-22750491

Bakıner, O. (2014). Can the 'spirit of Gezi' transform progressive politics in Turkey? In U. Özkırımlı (Ed.), The making of a protest movement in Turkey: \#occupygezi (pp. 65-76). Basingstoke: Palgrave Macmillan.

Benford, R., \& Snow, D. (2000). Framing processes and social movements: An overview and assessment. Annual Review of Sociology, 26, 611-639.

Birchall, C. (2006). Knowledge goes pop: From conspiracy theory to gossip. Oxford: Berg.

Bora, T. (1996). Komplo zihniyetinin ornek ulkesi Türkiye. Birikim, 90, 42-44

Bratich, J. (2008). Conspiracy panics: Political rationality and popular culture. Albany: State University of New York Press. 
Boudon, R. (1996). The 'cognitivist model': A generalized 'rational-choice model. Rationality and Society, 8, 123-150.

Boudon, R. (2001). The origin of values. New Brunswick, New Jersey: Transaction Publishers.

Boudon, R. (2003). Beyond rational choice theory. Annual Review of Sociology, 29, 1-21.

Boudon, R. (2008). How can axiological feelings be explained? International Review of Sociology: Revue Internationale de Sociologie, 18, 349-364.

Boudon, R. (2014). What is context? Kölner Zeitschrift für Soziologie und Sozialpsychologie, $66,17-45$.

Bronner, S. (2003). A rumor about the Jews: Anti-Semitism, conspiracy, and the Protocols of Zion. New York: Oxford University Press.

Byford, J. (2011). Conspiracy theories: A critical introduction. Basingstoke: Palgrave MacMillan.

Chakravarty, A., \& Chaudhuri, S. (2012). Strategic framing work(s): How microcredit loans facilitate anti-witch-hunt movements. Mobilization: An International Quarterly, 17, 175-194.

Coleman, J. (1990). Foundations of social theory. Cambridge, Mass.; London: Belknap Press of Harvard University Press.

Croft, A., \& Pawlak, J. (24 June, 2013). Germany proposes delaying EU-Turkey talks over protests. Reuters. Retrieved from http://www.reuters.com/article/2013/06/24/us-turkeyprotests-eu-idUSBRE95N19F20130624

Diken, B. (2014). The emancipated city: Notes on Gezi revolts. Journal for Cultural Research, 18, 315-328. doi: 10.1080/14797585.2014.959306 
Eken, B. (2014). The politics of the Gezi Park resistance: Against memory and identity. The South Atlantic Quarterly, 113, 427-436.

Farro, A., \& Demirhisar, D. (2014). The Gezi Park movement: A Turkish experience of the twenty-first-century collective movements. International Review of Sociology: Revue Internationale de Sociologie, 24, 176-189.

Fathi, S. (2014). From Mosaddeq to HAARP. In M. Reinkowski \& M. Butter (Eds.), Conspiracy theories in the United States and the Middle East: A comparative approach (pp. 59-75). Berlin: Walter De Gruyter.

Fenster, M. (1999). Conspiracy theories: Secrecy and power in American culture. Minneapolis, MN: University of Minnesota Press.

Gambetti, Z. (2014). Occupy Gezi as politics of the body.” In U. Özkırımlı (Ed.), The making of a protest movement in Turkey: \#occupygezi (pp. 89-102). Basingstoke: Palgrave Macmillan.

Gosa, T. (2011). Counterknowledge, racial paranoia, and the cultic milieu: Decoding hip hop conspiracy theory. Poetics, 39, 187-204.

Gray, M. (2010). Conspiracy theories in the Arab world. London: Routledge

Goertzel, T. (1994). Belief in conspiracy theories. Political Psychology, 15, 733-744.

Goffman, E. (1959). The presentation of self in everyday life. Garden City, N.Y.: Doubleday.

Goffman, E. (1975). Frame analysis: An essay on the organization of experience. London: Harper \& Row.

Göçek, M. (2011). The transformation of Turkey: Redefining state and society from the Ottoman Empire to the modern era. London: I. B. Tauris. 
Göle, N. (2013). Gezi-Anatomy of a public square movement. Insight Turkey, 15, 7-14.

Guida, M. (2008). 'The Sèvres syndrome' and 'komplo' theories in the Islamist and secular press. Turkish Studies, 9, 37-52.

Gürcan, E., \& Peker, E. (2014). Turkey's Gezi Park demonstrations of 2013: A Marxian analysis of the political moment. Socialism and Democracy, 28, 70-89.

Haaretz. (1 June, 2013). Erdoğan: For every 100,000 protesters, I will bring out a million from my party. Retrieved from http://www.haaretz.com/news/middle-east/1.527188

Halfmann, D., \& Young, M. (2010). War pictures: The grotesque as a mobilizing tactic. Mobilization: An International Quarterly, 15, 1-24.

Hart, J. R. (2008). Practicing Birchism: The assumption and limits of idiocultural coherence in framing theory. Social Movement Studies, 7, 121-147.

Hayes, A., \& Krippendorff, K. (2007). Answering the call for a standard reliability measure for coding data. Communication Methods and Measures, 1, 77-89

Hofstadter, R. (1965). The paranoid style in American politics and other essays. New York: Alfred A. Knopf.

Hürriyet Daily News. (27 June, 2013a). Turkish Prime minister vows to increase police force. Retrieved from http://www.hurriyetdailynews.com/turkish-prime-minister-vows-to-increasepolice-force.aspx?pageID $=238 \& n I D=49006 \&$ NewsCatID $=338$

Hürriyet Daily News. (5 August, 2013b). Germany behind Gezi protests to stop Istanbul's third airport: Ruling AKP lawmaker. Retrieved from http://www.hurriyetdailynews.com/germany-behind-gezi-protests-to-stop-istanbuls-thirdairport-ruling-akp-lawmaker.aspx?pageID=238\&nID=52032\&NewsCatID=338 
Iğsız, A. (2014). Brand Turkey and the Gezi protests: Authoritarianism in flux, law and neoliberalism. In U. Özkırımlı (Ed.), The making of a protest movement in Turkey: \#occupygezi (pp. 25-49). Basingstoke: Palgrave Macmillan.

Kavakç1, M. (2009). Turkey’s test with its deep state. Mediterranean Quarterly, 20, 83-97.

Keyder, C. (6 September, 2013). Gezi olaylarının seyrini Türkiye'de yükselmekte olan yeni orta sınıf değiştirmiştir. T24. Retrieved from http://t24.com.tr/haber/keyder-gezi-olaylarininseyrini-turkiyede-yukselmekte-olan-yeni-orta-sinif-degistirmistir,238849).

Knight, P. (2000). Conspiracy culture: From the Kennedy assassination to the X-Files. London: Routledge.

KONDA. (2014). Gezi report: Public perception of the 'Gezi protests.' Retrieved from http://www.konda.com.tr/en/raporlar/KONDA_Gezi_Report.pdf

Kuymulu, B. (2013). Reclaiming the right to the city: Reflections on the urban uprisings in Turkey. City: analysis of urban trends, culture, theory, policy, action, 17, 274-278.

Leenders, R. (2012). Collective action and mobilization in Dar'a: An anatomy of the onset of Syria's popular uprising. Mobilization: An International Quarterly, 17, 419-434.

Locke, S. (2009). Conspiracy culture, blame culture, and rationalization. The Sociological Review, 57, 567-585.

Lombard M., Snyder-Duch, J., \& Bracken, C. (2002). Content analysis in mass communication assessment and reporting of intercoder reliability. Human Communication Research, 28, 587-604.

Melley, T. (2000). Empire of conspiracy: The culture of paranoia in postwar America. London: Cornell University Press. 
Mello, B. (2007). Political process and the development of labor insurgency in Turkey, 194580. Social Movement Studies, 6, 207-225.

Moudouros, N. (2014). Rethinking Islamic hegemony in Turkey through Gezi Park. Journal of Balkan and Near Eastern Studies, 16, 181-195.

Nefes, T. S. (2012) The history of the social constructions of Dönmes (converts). Journal of Historical Sociology, 25, 413-439.

Nefes, T. S. (2013) Political parties' perceptions and uses of anti-Semitic conspiracy theories in Turkey. The Sociological Review, 61, 247-264.

Nefes, T. S. (2014) Rationale of conspiracy theorizing: who shot the president Chen Shuibian? Rationality and Society, 26, 373-394.

Nefes, T. S. (2015a) Scrutinizing impacts of conspiracy theories on readers' political views: a rational choice perspective on anti-Semitic rhetoric in Turkey. British Journal of Sociology, 66, 557-575.

Nefes, T. S. (2015b) Understanding the anti-Semitic rhetoric in Turkey through the Sevres syndrome. Turkish Studies, 16, 572-587.

Oliver, E., \& Wood, T. (2014). Conspiracy theories and the paranoid style(s) of mass opinion. American Journal of Political Science, 58, 952-966.

Olmsted, K. (2009). Real enemies: Conspiracy theories and American democracy, World War I to 9/11. New York: Oxford University Press.

Örs, I. (2014). Genie in the bottle: Gezi park, Taksim square, and the realignment of democracy and space in Turkey. Philosophy and Social Criticism, 40, 489-498. 
Özbudun, E. (2014). AKP at the crossroads: Erdoğan's majoritarian drift. South European Society and Politics, 19, 155-167.

Pipes, D. (1997). Conspiracy: How the paranoid style flourishes and where it comes from. New York: Free Press.

Potter, J., \& Levine-Donnerstein, D. (1999). Rethinking validity and reliability in content analysis. Journal of Applied Communication Research, 27, 258-284.

Reuters. (12 September, 2013). Turkish Jews worried after politician links diaspora to protests. Retrieved from http://www.reuters.com/article/2013/07/02/us-turkey-protests-jewsidUSBRE9610L520130702

Robins, P. (2003). Suits and uniforms: Turkish foreign policy since the Cold War. Seattle: University of Washington Press.

Robins, R. \& Post, J. (1997). Political paranoia: The psycho-politics of hatred. New Haven, CT: Yale University Press.

Rydgren, J. (2004). The logic of xenophobia. Rationality and Society, 16, 123-148.

Snow, D., Tan, A., \& Owens P. (2013). Social movements, framing processes, and cultural revitalization and fabrication. Mobilization: An International Quarterly, 18, 225-242.

Üngör, U. Ü. (2011). The making of modern Turkey: Nation and state in eastern Anatolia, 1913-1950. Oxford: Oxford University Press.

Webb, E. (2011). Resisting anamnesis: A Nietzschean analysis of Turkey’s national history education. Journal of Contemporary European Studies, 19, 489-500.

Y1lmaz, H. (2011). Euroscepticism in Turkey: Parties, elites and public opinion. South European Society and Politics, 16, 185-208. 
Table 1. Online users' responses to the conspiracy theory.

\begin{tabular}{|l|l|}
\hline Category & Examples \\
\hline Accept & $\begin{array}{l}\text { "This is the lobby that has been exploiting the Turkish economy and } \\
\text { has been discussed in Turkey for years. With the Gezi Park protests } \\
\text { their existence became obvious." }\end{array}$ \\
\hline Reject & $\begin{array}{l}\text { "Erdoğan knows that they have nothing to do with the Gezi Park } \\
\text { protests, but as this lobby brought him to power, he fears that they will } \\
\text { replace him..." }\end{array}$ \\
\hline
\end{tabular}

Table 2. Perception of the conspiratorial rhetoric and political view.

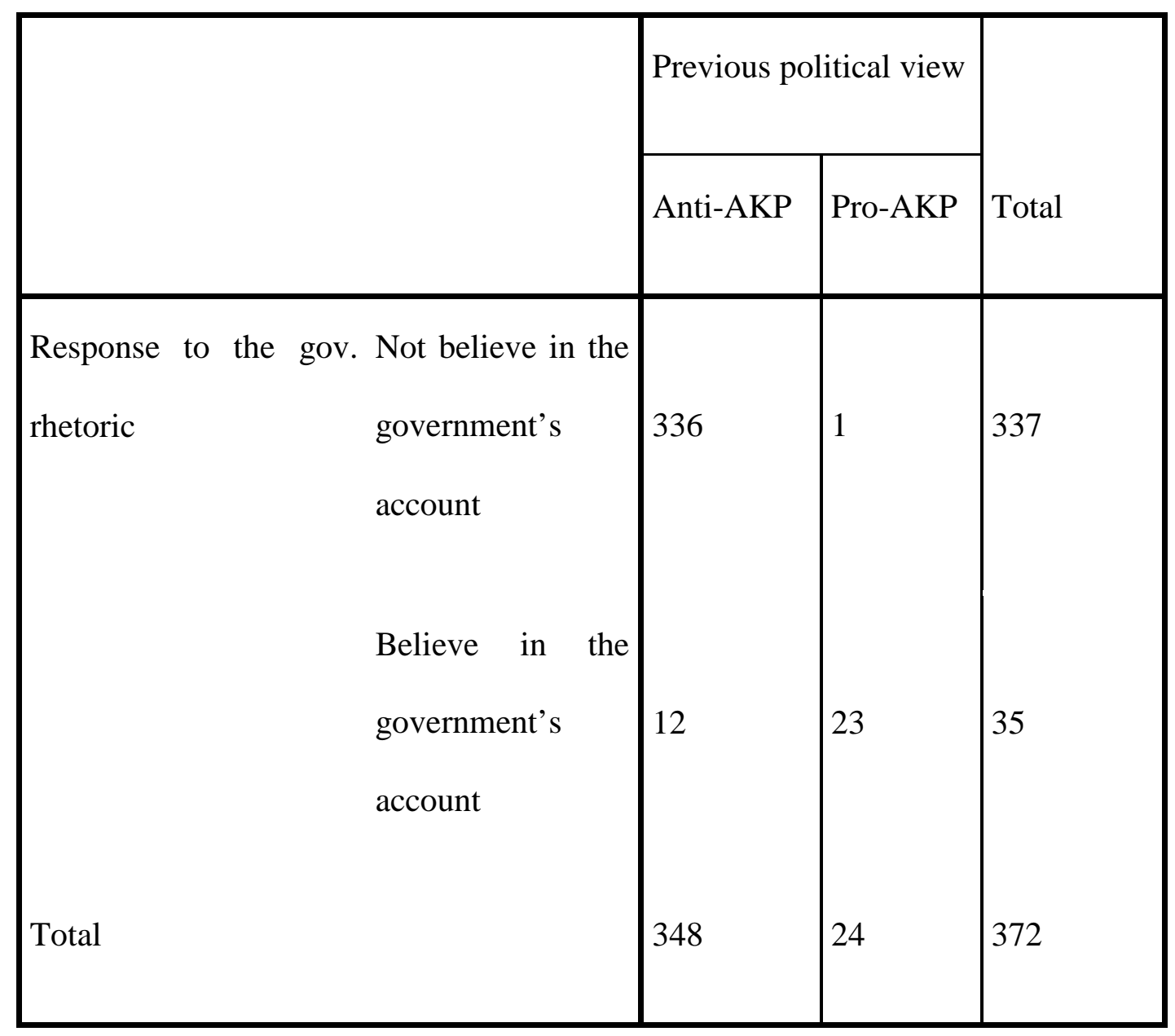


Table 3. Classification Table. ${ }^{\mathrm{a}}$

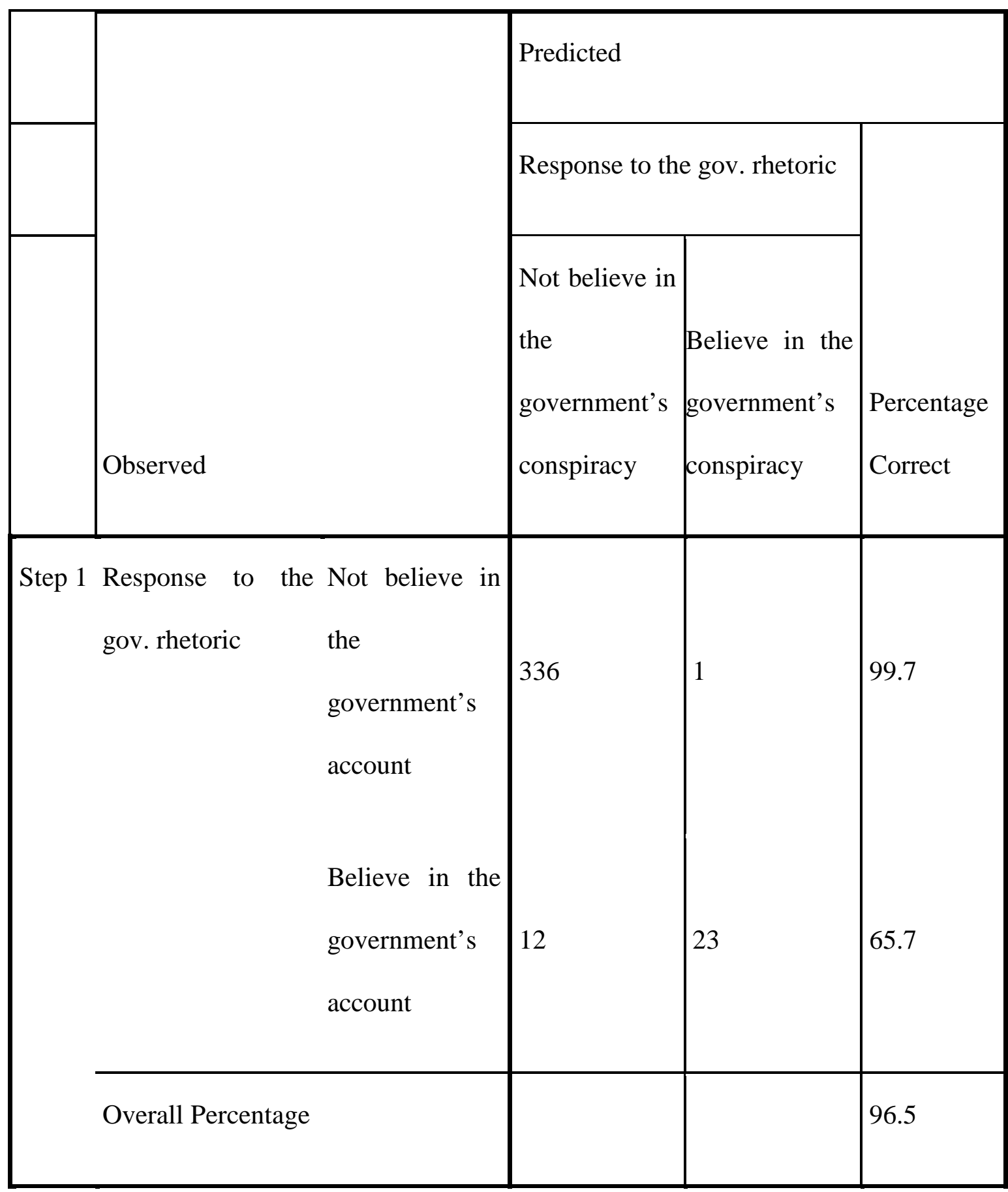

a. The cut value is .500 
Table 4. Ways of rejecting the conspiratorial rhetoric.

\begin{tabular}{|l|l|}
\hline Interpretation & Examples \\
\hline Erdoğan right & “The interest rate lobby exists!” \\
\hline The conspiracy & "Despite the fact that the Prime Minister wants to make Istanbul a \\
form & global financial centre, he complains about the interest rate lobby! \\
\hline Erdoğan wrong & "If they do not raise my salary, I will unveil their identity!” \\
\hline AKP propaganda & “A good example of inventing an imaginary enemy.” \\
\hline
\end{tabular}

